\title{
2. The nature and prevalence of internships ${ }^{1}$
}

\section{Andrew Stewart}

\subsection{INTRODUCTION}

There is no universally accepted definition of an internship. The term originated in the context of medical education, where it is still used to denote a period early in the postgraduate training of doctors during which they work under supervision in hospitals for relatively low pay. From the 1930s in the USA, 'internship' was adopted to describe programmes that gave young people the opportunity to work in government and (later) political organizations. However, the recent explosion of such arrangements, especially in higher-income countries, means that interns can now be found in a wide range of industries and occupations, working for businesses, not-for-profit organizations and government agencies alike. ${ }^{2}$

In today's highly competitive labour market, internships may be undertaken to satisfy the requirements of education or training courses, or be offered to unemployed job seekers by employment service providers as part of active labour-market programmes (or policies) (ALMPs). They may be established by businesses to offer a taste of what work is like in a particular profession, or to test out applicants. Alternatively, they may simply be arrangements initiated by job seekers themselves, in order to gain contacts or to fill out a résumé. These last two categories are often termed 'open-market' internships. All of these forms of internship are 'work-based schemes whose purpose is to provide skills and knowledge in the workplace'. ${ }^{3}$

1 This chapter contains material originally published in the report by Andrew Stewart and others referred to in $\mathrm{n} 31$. Some of that material also appears in sections 1.5 and 6.2 of the ILO report cited in $\mathrm{n} 21$. I am grateful to Irene Nikoloudakis for her assistance with research for both the original and updated versions.

2 Ross Perlin, Intern Nation: How to Earn Nothing and Learn Little in the Brave New Economy (rev edn, Verso Books 2012).

3 Ana Jeannet-Milanovic, Niall O'Higgins and Annika Rosin, 'Contractual Arrangements for Young Workers' in Niall O'Higgins (ed), Rising to the Youth 
The scale of the internship phenomenon was nicely captured by The Economist:

The internship - a spell of CV-burnishing work experience - is now ubiquitous across America and beyond. This year young Americans will complete perhaps $1 \mathrm{~m}$ such placements; Google alone recruited 3,000 interns this summer, promising them the chance to 'do cool things that matter'. Brussels and Luxembourg are the summer homes of 1,400 stagiaires, or embryonic Eurocrats, doing five-month spells at the European Commission. The 'Big Four' audit companies - Deloitte, Ernst \& Young, KPMG and PricewaterhouseCoopers (PwC) - will employ more than 30,000 interns this year. Bank of China runs an eight-week programme ('full of contentment, yet indescribable', according to an intern quoted on its website); Alibaba, a Chinese online-retailing behemoth, has a global scheme. Infosys, an Indian tech giant, brings 150 interns from around the world to Bangalore each year. ${ }^{4}$

As discussed further in section 2.6 of this chapter, many concerns have been expressed in recent years about the role and effectiveness of internships as a bridge between education and (paid) work. These were summarized by the Council of the European Union (EU) in these terms:

Socio-economic costs arise if traineeships, particularly repeated ones, replace regular employment, notably entry-level positions usually offered to trainees. Moreover, low-quality traineeships, especially those with little learning content, do not lead to significant productivity gains nor do they entail positive signalling effects. Social costs can also arise in connection with unpaid traineeships that may limit the career opportunities of those from disadvantaged backgrounds. ${ }^{5}$

The Council's response was to adopt a Quality Framework for Traineeships, with the intention of helping EU member states to '[i]mprove the quality of traineeships, in particular as regards learning and training content and working conditions, with the aim of easing the transition from education, unemployment or inactivity to work' ${ }^{6}$

Employment Challenge: New Evidence on Key Policy Issues (International Labour Office 2017) 143.

4 The Economist, 'The Internship: Generation i' The Economist (12 September 2014), www.economist.com/international/2014/09/12/generation-i, accessed 30 March 2021.

5 Council Recommendation of 10 March 2014 on a Quality Framework for Traineeships [2014] OJ C88/1, preamble, para 4.

6 Ibid recommendation 1. For discussion of the extent to which the Quality Framework for Traineeships has been implemented by EU members, see European Commission, 'Applying the Quality Framework for Traineeships' (2016) European Commission Staff Working Document 324; Lukasz Sienkiewicz, Traineeships under the Youth Guarantee: Experience from the Ground (European Commission 2018). See also Valli Corbanese and Gianni Rosas, Assessing the Quality Dimensions of 
In June 2012, as part of a resolution concerning the 'youth employment crisis', the International Labour Conference noted that 'internships, apprenticeships, and other work experience schemes have increased as ways to obtain decent work. However, such mechanisms can run the risk, in some cases, of being used as a way of obtaining cheap labour or replacing existing workers'? The resolution invited 'social partners' (trade unions and employers) not just to encourage enterprises to provide more internships or apprenticeships, but to engage in collective bargaining to improve the working conditions of interns and apprentices, and indeed to 'raise awareness' about the labour rights of young workers. ${ }^{8}$

An article on the website of the International Labour Organization (ILO) subsequently warned of the dangers if internships become simply a 'disguised form of employment' without any of the benefits they promise, such as real on-the-job training. ${ }^{9}$ The importance of all forms of work experience, be they internships or apprenticeships, providing a quality learning experience and thereby a gateway to good quality and decent jobs, rather than being used to replace paid employees, has been reiterated in other global fora, including the G20. ${ }^{10}$

Against that background, this chapter reviews what is known about internships - what they are, how they can be categorized and how common they are - and summarizes some of the policy concerns that will be explored in other chapters in this volume.

\subsection{DEFINING AND DISTINGUISHING INTERNSHIPS}

As Perlin notes, 'what defines an internship depends largely on who's doing the defining'. ${ }^{11}$ He says of the word 'intern' that it is 'a kind of smokescreen, more brand than job description, lumping together an explosion of intermittent

Youth Employment Offers (International Labour Office 2017), a guide to quality traineeships prepared jointly by the International Labour Organization and the European Commission.

7 ILO, 'The Youth Employment Crisis: A Call for Action' (Resolution and Conclusions of the 101st Session of the International Labour Conference 2012) para 24.

8 Ibid para 27.

9 ILO, 'Internships: Head Start or Labour Trap?' (22 August 2012), www.ilo.org/ global/about-the-ilo/newsroom/features/WCMS_187693/lang--en/index.htm, accessed 30 March 2021.

10 See eg Organisation for Economic Co-operation and Development and ILO, Promoting Better Labour Market Outcomes for Youth (Report prepared for the G20 Labour and Employment Ministerial Meeting, OECD and ILO 2014) 11.

11 Perlin (n 2) 25-6. 
and precarious roles we might otherwise call volunteer, temp, summer job, and so on' ${ }^{12}$ The term can also have different connotations in different countries. ${ }^{13}$ In the UK, for example, internships are generally or primarily understood to be forms of work experience undertaken after completion of higher or technical education, as opposed to the 'placements' that may form part of educational programmes. In nations such as the US, by contrast, it is just as common to speak of students undertaking internships as it is graduates.

An internship is a form of work-based learning. In the most general sense, this learning can occur as a natural incident of any type of work arrangement: merely doing a job can result in new or enhanced competencies. However, the term 'work-based learning' is generally used to refer to a programme or arrangement that is designed to have that result. In a recent review of research on the topic, Comyn and Brewer take work-based learning programmes to be 'those which include the process of undertaking and reflecting on productive work in real workplaces, paid or unpaid, and which may or may not lead to formal certification'. ${ }^{14}$ As they note, many different typologies have been adopted. One, developed within the ILO, identifies seven broad possibilities, based on whether there is a contract between 'employer' and learner, whether the outcomes are officially recognized or certified, and whether the training is delivered on or off the job. ${ }^{15}$ But it is more common to find references to four broad categories: apprenticeships, informal apprenticeships, internships and traineeships. ${ }^{16}$

In their modern sense, apprenticeships are generally understood as "programmes of learning that combine part-time formal education with training and experience at the workplace, and result in an externally recognised vocational qualification' ${ }^{17}$ This reflects a 'dualist ideal: the synthesis of theory and practice, on the one hand, and of the classroom and the workplace, on the

12 Ibid xi.

13 The same can be said of broadly equivalent terms in other languages, such as stagiaire (French), pasante (Spanish) or praktikant (German).

14 Paul Comyn and Laura Brewer, 'Does Work-Based Learning Facilitate Transitions to Decent Work?' (2018) International Labour Office Employment Policy Department Working Paper No 242, 6.

15 Ibid 4-5.

16 Hilary Steedman, 'Overview of Apprenticeship Systems and Issues' (Contribution to the G20 Task Force on Employment, ILO 2012) 3; ILO, ILO Toolkit for Quality Apprenticeships, Volume 1: Guide for Policy Makers (International Labour Office 2017) 6-7.

17 Paul Ryan, 'Apprenticeship: Between Theory and Practice, School and Workplace' in Matthias Pilz (ed), The Future of Vocational Education and Training in a Changing World (VS Verlag für Sozialwissenschaften 2012) 405. 
other'. ${ }^{18}$ What distinguishes apprenticeships from even the more formal kinds of internship is the scope of the training involved. Apprenticeships are more likely to operate over longer periods, and they necessarily involve training in all of the competencies required to practise a particular trade or profession. By contrast, most internships tend to be for shorter periods, and to focus on gaining general experience in a type of work or offering an opportunity to practise skills already acquired. ${ }^{19}$

Informal apprenticeships, by contrast, embody an older model of training for a craft or profession. As Steedman explains:

In order to pass on skills from one generation to the next, poor societies have developed informal apprenticeship systems that are purely workplace-based. A young apprentice learns by way of observation and imitation from an experienced master craftsperson, acquires the skills of the trade and is inducted into the culture and networks of the business. Apprenticeship agreements are mostly oral, yet they are embedded in the society's customs, norms and traditions ... Today, informal apprenticeship is an extensive training system in countries with large informal economies all over the world, including in South Asia, known as the ustad-shagird system. Variations in terms of practices are wide, yet the basic feature remains the same: the training agreement between a young learner and an experienced craftsperson to transmit the skills of a trade. ${ }^{20}$

As for a traineeship, this term is often used as a synonym for internship. In that vein, for example, the Council of the EU has defined a traineeship as 'a limited period of work practice, whether paid or not, which includes a learning and training component, undertaken in order to gain practical and professional experience with a view to improving employability and facilitating transition to regular employment'. ${ }^{21}$ However, the word can also, in some countries, denote an entire training arrangement, not just the work-based component. In Australia, for example, a traineeship is a structured, employment-based training programme that leads to the trainee gaining a nationally recognized qualification. The main differences compared with an apprenticeship are that

18 Ibid 404.

19 ILO, Upgrading Informal Apprenticeship: A Resource Guide for Africa (International Labour Office 2012) 8; Kari P Hadjivassiliou, Emanuela Carta, Tom Higgins, Catherine Rickard, Suzanne Ter-Minassian, Flavia Pesce and others, Study on a Comprehensive Overview on Traineeship Arrangements in Member States: Final Synthesis Report (European Union 2012) 52.

20 Steedman (n 16) 4.

21 Council Recommendation on a Quality Framework for Traineeships (n 5) para 27. See also ILO, A Framework for Quality Apprenticeships (International Labour Office 2019) 80, which proposes a definition of the term 'traineeship' to include an internship and to mean 'any form of on-the-job learning, which enables a person (the "trainee") to acquire work experience with a view to enhancing their employability'. 
an Australian traineeship can involve part-time employment, typically lasts for one to two years (as opposed to three to four years for apprenticeships), and is generally for an occupation not traditionally recognized as involving a 'trade'. ${ }^{22}$ The 'learnerships' available in South Africa as an alternative to apprenticeships have broadly similar features, although unlike their Australian equivalents they are not considered to involve an employment relationship. ${ }^{23}$ Both Australian traineeships and South African learnerships might well fall within a sufficiently broad definition of 'apprenticeship'.

For the purpose of this chapter, an internship is taken to be any arrangement for the performance of work within a business or organization, a primary purpose of which is to gain experience, skills and/or contacts that will assist the worker to gain employment or other work opportunities in the future, but which does not seek in a structured way to provide all the skills needed for a particular occupation.

A final concept that needs to be distinguished in this context is volunteering, which in its true form denotes unpaid work that is performed with the primary purpose of benefiting someone else or furthering a particular belief, rather than gaining experience, skills or contacts that may enhance employability. ${ }^{24}$ Interns frequently 'volunteer' their services without remuneration, in the hope of gaining increased employability or a future job. And the line between volunteering and internship can become particularly blurred where the host organization is a not-for-profit body that seeks to assist others (such as a charity) or is associated with a particular cause or belief (such as a political party or a religious institution). In such cases, unpaid work may be undertaken both to increase employability and as an act of altruism or ethical commitment. ${ }^{25}$

22 See eg Department of Training and Workforce Development, 'Apprenticeships and Traineeships' (Government of Western Australia, 2019), www.jobsandskills.wa .gov.au/training/apprenticeships-and-traineeships, accessed 30 March 2021.

23 Erica Smith and Ros Brennan Kemmis, Towards a Model Apprenticeship Framework: A Comparative Analysis of National Apprenticeship Systems (ILO and World Bank 2013) 6, 120.

${ }^{24}$ Andrew Stewart and Rosemary Owens, Experience or Exploitation? The Nature, Prevalence and Regulation of Unpaid Work Experience, Internships and Trial Periods in Australia (Fair Work Ombudsman 2013) 5. Compare the United Nations definition of 'activities ... undertaken of free will, for the general public good and where monetary reward is not the principal motivating factor': United Nations Volunteers, State of the World's Volunteerism Report: Transforming Governance (United Nations Volunteers 2015) xxiii.

${ }^{25}$ See eg Pauline Leonard, Susan Halford and Katie Bruce, “"The New Degree?" Constructing Internships in the Third Sector' (2016) 50 Sociology 383. 
Nevertheless, the focus in this chapter is on non-altruistic arrangements for gaining work experience. ${ }^{26}$

\subsection{TYPES OF INTERNSHIP}

In classifying internships, an obvious distinction is between those that are paid and those that are unpaid. An internship may be regarded as paid if the intern receives financial compensation, in the form of a wage or stipend, although perhaps not if they simply receive reimbursement for a very limited range of expenses (such as travel costs).

In a practical sense, there may be little reason for concern with internships that involve remuneration that at least matches the minimum wage which would otherwise apply to employees performing the same work. It is likely in this situation that the interns concerned will be treated as employees. ${ }^{27}$

Generally, the internships that raise the type of policy concerns outlined in section 2.6 of this chapter will tend to be those that are either unpaid or that attract compensation below the legal minimum for employees. Nevertheless, there may still be important regulatory issues with paid interns who are not treated as employees, in relation to matters such as hours of work, safety, freedom from discrimination and so on. ${ }^{28}$

A further distinction may be drawn between internships that involve 'real' or productive work - work that benefits the host business or organization - and those that are limited mostly to observation or mock tasks. Again, the latter type may be of less concern, in so far as the host would have no incentive to use them in place of paid employees, or (given the costs of supervision) to have the arrangement extend for a lengthy period. Indeed, interns in that category are far less likely to qualify as employees, even in countries with a broad definition of that class. Nevertheless, it may still be important to consider the regulation of these arrangements in relation to matters other than remuneration.

\footnotetext{
26 Compare the more nuanced distinction drawn by Murray between 'genuine' and 'precarious' volunteer work in Jill Murray, 'The Legal Regulation of Volunteer Work' in Christopher Arup, Peter Gahan, John Bellett Howe, Richard Stephen Johnstone, Richard Mitchell and Anthony O'Donnell (eds), Labour Law and Labour Market Regulation: Essays on the Construction, Constitution and Regulation of Labour Markets and Work Relationships (Federation Press 2006) 697-8.

27 That is the case in the way labour-market statistics are to be gathered under current, internationally agreed standards, as discussed in section 2.5 of this chapter.

28 Rosemary Owens and Andrew Stewart, 'Regulating for Decent Work Experience: Meeting the Challenge of the Rise of the Intern' (2016) 155 Int Lab Rev 679, 705.
} 
Yet another way of categorizing internships or traineeships is to divide them into three categories that are based on their purpose or function. ${ }^{29}$ These are (1) placements associated with formal education or training programmes run by authorized institutions or providers; (2) periods of work experience associated with ALMPs designed by governments or employment service providers to assist the unemployed; and (3) other, open-market internships. ${ }^{30}$ This is an especially useful typology for legal purposes, since in many countries different rules or processes apply to each of those categories, at least for specific regulatory purposes. ${ }^{31}$ The reason for this is often said or assumed to lie in the different governance arrangements for the three types of internship. ${ }^{32}$ For example, the EU's Quality Framework for Traineeships is expressly stated not to cover 'work experience placements that are part of curricula of formal education or vocational education and training', nor traineeships whose content is regulated under national law and which must be completed to enter a particular profession. ${ }^{33}$ This omission has been justified on the basis that 'traineeships which belong to these categories are in general of better quality, due to the quality assurance by the educational institutions or professional organisations involved' ${ }^{34}$ Indeed, it is common for regulatory regimes to have an exemption for educational internships. ${ }^{35}$

29 Compare Grant-Smith and McDonald, who conceptualize unpaid work according to two dimensions: 'participatory discretion' (whether it is mandatory or elective) and purpose (educational or productive). See Deanna Grant-Smith and Paula McDonald, 'Ubiquitous Yet Ambiguous: An Integrative Review of Unpaid Work' (2018) 20 IJMR 559.

30 See eg Hadjivassiliou and others (n 19) 4-5. A fourth possible category covers internships undertaken as a mandatory part of professional training, as opposed to 'educational curricula': see eg Sienkiewicz (n 6) 4. But state-regulated examples of this training can usually be equated to other types of educational internships, while those which operate without official authorization will generally have the same legal status as open-market internships.

31 Andrew Stewart, Rosemary Owens, Anne Hewitt and Irene Nikoloudakis, 'The Regulation of Internships: A Comparative Study' (2018) International Labour Office Employment Policy Department Working Paper No 240, chs 7-9.

32 David Lain, Kari Hadjivassiliou, Antonio Corral Alza, Iñigo Isusi, Jacqueline O'Reilly, Victoria Richards and others, 'Evaluating Internships in Terms of Governance Structures: Contract, Duration and Partnership’ (2014) 38 Eur J Train Dev 588.

33 Council Recommendation on a Quality Framework for Traineeships (n 5) preamble, para 28 .

34 European Commission, 'Applying the Quality Framework for Traineeships' (n 6) 4.

35 Stewart and others (n 31) 51-4. 
Similarly, while the EU Quality Framework for Traineeships does cover ALMP traineeships, it often seems to be assumed that these should attract less concern than those in the open market:

In the case of open market traineeships there is no third party involved further to the trainee and the host organisation, which also means that the quality assurance of the traineeship becomes more difficult. ALMP-type traineeships, on the other hand, are offered to (young) unemployed or those at risk of becoming unemployed, and there is usually a public institution (most often a PES [public employment service]) acting as an intermediary between the host organisation and the trainee. This intermediary institution also has a supervising function in terms of traineeship quality. ${ }^{36}$

This is not to say, however, that these explanations should be uncritically accepted. Indeed, it can be argued that, even if educational or ALMP internships should attract different rules or requirements, this should only be the case where specific preconditions are satisfied - and that there are some labour standards that should apply regardless of the type of internship involved ${ }^{37}$ That issue is taken up in the conclusion to this volume in Chapter 20.

A further possible distinction is between internships that are confined to one jurisdiction and those with an international or transnational element. It has become common in recent years for students or graduates to seek to undertake internships in another country. These opportunities are often considered highly prestigious, as with opportunities to work as an intern for agencies of the United Nations or other international organizations, such as the Red Cross and Red Crescent. In part, this reflects a belief that the internationalization of work-based learning can help create 'global citizens' who can more readily find jobs and fill skill shortages around the world ${ }^{38}$ - even though the evidence suggests that only a minority of employers consider international experience when making recruitment decisions. ${ }^{39}$

Reflecting this trend, there are now agencies that broker overseas internships - a service for which they demand a fee. ${ }^{40}$ Often implicit in what these agencies offer is a promise that internships will open up not only entry to the labour market, but access to the citizenship of the destination country. Educational

\footnotetext{
36 European Commission, 'Applying the Quality Framework for Traineeships' (n 6) 4.

37 Stewart and others (n 31) 86-7.

38 See eg Natalie Gamble, Carol-Joy Patrick and Deborah Peach, 'Internationalising Work-Integrated Learning: Creating Global Citizens to Meet the Economic Crisis and the Skills Shortage' (2010) 29 Higher Educ Res Dev 535.

39 Christof Van Mol, 'Do Employers Value International Study and Internships? A Comparative Analysis of 31 Countries' (2017) 78 Geoforum 52.

$40 \quad$ See eg Perlin (n 2) ch 6; Paula McDonald, 'Open Market Internships: What Do Intermediaries Offer?’ (2020) 33 J Educ \& Work 33.
} 
institutions, which often encourage and facilitate exchange arrangements for students, may promote the opportunity to undertake internships in other countries as part of these arrangements. Transnational corporations and businesses may also place interns or trainees in another country, sometimes as part of the transnational delivery of contracts for specific services, or to promote or emphasize generally what are perceived to be attractive work opportunities offered by their global reach. ${ }^{41}$ International internships are a new form of temporary labour migration, sometimes facilitated by a new type of migration agent (an educational institution, a commercial broker or a transnational firm).

International internships may also be promoted by government programmes. These may seek to provide incentives to the citizens of a country to undertake work experience abroad, whether out of a belief in the intrinsic value of such arrangements, or to improve engagement with a particular region. ${ }^{42}$ Conversely, they may provide opportunities for foreign students or workers to come and study in the government's own country, to boost economic development either in that country or in the foreign interns' home nations. ${ }^{43}$

\subsection{EVIDENCE ON THE PREVALENCE OF INTERNSHIPS}

The clearest data on the prevalence of internships come from Europe and Australia. In 2013, a survey conducted for the European Commission in the 27 countries that were then members of the EU found that 46 per cent of people aged from 18 to 35 had undertaken at least one (and often more than one) traineeship, understood for this purpose to mean 'a limited period of work experience and training spent in a business, public body or non-profit institution by students or young graduates'. The proportion ranged from as high as 79 per cent in the Netherlands and 74 per cent in Germany, to only 8 per cent in Lithuania and Slovakia. Fifty-nine per cent of respondents who had undertaken

41 Significantly, regulatory regimes for global trade may treat interns or trainees in ways that are distinct from other workers: Samuel Engblom, Nicola Kountouris and Åsa Odin Ekman, 'Temporary Labour Migration and the Trade in Services: European and Global Perspectives in an Age of Economic Integration' in Joanna Howe and Rosemary Owens (eds), Temporary Labour Migration in the Global Era: The Regulatory Challenges (Hart Publishing 2016).

${ }_{42}$ As, for instance, with Australia's New Colombo Plan, which provides Australian students with assistance to undertake internships in the Asia-Pacific region: see Department of Foreign Affairs and Trade, 'New Colombo Plan' (Australian Government), http://dfat.gov.au/people-to-people/new-colombo-plan/ pages/new-colombo-plan.aspx, accessed 30 March 2021.

43 The Japanese Technical Internship Programme has been a significant, if controversial, example of this: see Stewart and others (n 31) 37-8. 
a traineeship reported that their most recent arrangement was unpaid, while of those receiving some form of compensation, less than half considered that the amount was sufficient to live on. ${ }^{44}$

A more recent study in the UK found that 46 per cent of graduates under 24 had done an internship, and the same proportion of employers reported offering internships. Seventy per cent of these internships involved no remuneration, or remuneration below the national minimum wage, although the number of these arrangements appeared to be falling. Fifty-three per cent of these unpaid (or underpaid) internships were over four weeks in length, with 11 per cent lasting over six months. ${ }^{45}$

In Australia, a national survey of arrangements involving unpaid work experience was undertaken in 2016. It found that 34 per cent of working-age adults had undertaken at least one such episode in the last five years, with the proportion rising to 58 per cent for those aged under 30 . One in five participants had undertaken five or more episodes in the past five years. A majority of episodes lasted for less than a month, although one in ten exceeded six months. Of the most recent experiences, half were associated with some form of formal education or training, whether at university (20 per cent), as part of vocational education or training (19 per cent) or at secondary school (10 per cent). Nearly one in ten ( 8 per cent) had participated as a requirement of maintaining access to unemployment benefits from the government, or as part of an unpaid trial while applying for a job ( 9 per cent). A further 4 per cent said they had been offered a paid job and the work experience was part of their training or orientation. Almost one in three (30 per cent) nominated some other reason for undertaking unpaid work experience, which would clearly cover open-market internships. ${ }^{46}$

44 TNS Political \& Social, The Experience of Traineeships in the EU (Flash Eurobarometer 378, Directorate-General for Employment, Social Affairs and Inclusion, European Commission 2013). The survey was conducted by telephone and involved 12921 respondents from different social and demographic groups across the EU: ibid 4.

45 Carl Cullinane and Rebecca Montacute, Pay As You Go? Internship Pay, Quality and Access in the Graduate Jobs Market (Sutton Trust 2018). The data in the report are taken primarily from two online surveys: one of 1003 leaders from businesses across a wide range of industries and representative of business size in the UK, and the other of 2614 young (21-29) graduates: ibid 11-12.

46 Damian Oliver, Paula McDonald, Andrew Stewart and Anne Hewitt, Unpaid Work Experience in Australia: Prevalence, Nature and Impact (Department of Employment 2016). In total, 3800 working age adults (18-64) were surveyed online, with the sample weighted to reflect the distribution of the relevant population by sex and age: ibid 4-5. Note that this survey, unlike the European survey, did not ask about paid internships. Subsequent analysis of the survey data has revealed that at least 10 per cent of unpaid work experience arrangements undertaken in Australia may be unlawful: see Andrew Stewart, Damian Oliver, Paula McDonald and Anne Hewitt, 'The Nature 
In other developed countries, firm statistics are harder to find, though it seems clear that internships have become extremely common. In the USA, for example, Carnevale and Hanson quote estimates (from 2010 and 2013) that interns represented 1.3 per cent of the labour force, with around half of all college students reporting having completed internships during their studies, around 50 per cent of which were unpaid. ${ }^{47}$ By contrast, it is likely that there are fewer interns in low- and middle-income countries, given the prevalence there of informal employment arrangements that may fill a similar niche in the labour market. ${ }^{48}$ Nevertheless, it is notable that countries such as Brazil and China have each passed laws in recent years to regulate internships. ${ }^{49}$

\subsection{OFFICIAL LABOUR STATISTICS ON INTERNSHIPS ${ }^{50}$}

Statistics provide the factual evidence which underpins, and so has consequences for, policy and regulation; therefore, the ways in which statisticians categorize internships and traineeships are important. An important development has been the passage of the Resolution Concerning Statistics on Work Relationships at the 20th International Conference of Labour Statisticians in $2018 .^{51}$ This defines a 'work activity' as 'a set of tasks and duties performed, or meant to be performed, by one person for a single economic unit'. ${ }^{2}$

The resolution proposes two distinct systems of classification. The International Classification of Status in Employment (ICSE 18) identifies ten types of employed persons, one of which is "paid apprentices, trainees and interns'. This category covers:

employees who perform any activity to produce goods or provide services for others, in order to acquire workplace experience or skills in a trade or profession and receive payment in return for work performed. Acquiring 'workplace experience or

and Prevalence of Unlawful Unpaid Work Experience in Australia' (2018) 31 AJLL 157.

47 Anthony P Carnevale and Andrew Hanson, 'Learn \& Earn: Career Pathways for Youth in the 21st Century' (2015) 4(1) EJICLS 76, 82-3.

48 Niall O'Higgins, Jonas Bausch and Francesca Bonomelli, 'The Quality of Work: Informal Employment in Low- and Middle-Income Countries' in Niall O'Higgins (ed), Rising to the Youth Employment Challenge: New Evidence on Key Policy Issues (International Labour Office 2017).

49 See eg Lei do Estágio (Law No 11788 of 2008) (Brazil); Regulations on the Management of Vocational School Student Internships, 2016 (China).

50 This section draws on material originally written by Rosemary Owens.

51 Resolution Concerning Statistics on Work Relationships (Resolution I, 20th International Conference of Labour Statisticians in Geneva, 10-19 October 2018).

52 Ibid para 8. 
skills' may occur through traditional, formal or informal arrangements whether or not a specific qualification or certification is issued. They are usually remunerated at a reduced rate compared to fully qualified workers. ${ }^{53}$

However, it excludes workers who are 'undertaking general on-the-job training or life-long learning while in employment', or working without pay. ${ }^{54}$

The ICSE 18 classifies employment status in two different ways. One is according to the type of authority (control) exercised. For that purpose, workers may either be independent (including employers or independent workers without employees) or dependent (dependent contractors, employees or contributing family workers). The other classification is by economic risk, with workers being employed either for profit (independent workers in household market enterprises, dependent contractors or contributing family workers) or for pay (owner-operators of corporations or employees). In both instances, paid apprentices, trainees and interns are counted as employees..$^{55}$

The other (and broader) system of classification is the International Classification of Status at Work (ICSaW-18), which at its most detailed contains 20 different categories. Paid apprentices, trainees and interns are one of those categories, and again are treated as employees, within a broader group of dependent workers. Also treated as dependent workers, but not as employees, are 'unpaid trainees', 'organization-based volunteers' and 'other unpaid workers' ${ }^{56}$ Unpaid trainee workers are 'persons in unpaid trainee work as defined in the most recent international statistical standards concerning work, employment and labour underutilization'. ${ }^{57}$

This last is a reference to a 2013 resolution by the International Conference of Labour Statisticians, which has for many other purposes been superseded by the 2018 statement. ${ }^{58}$ The earlier resolution defines persons in unpaid trainee work as 'all those of working age who, during a short reference period, performed any unpaid activity to produce goods or provide services for others, in order to acquire workplace experience or skills in a trade or profession' ${ }^{59}$

\section{Ibid para 55.}

$54 \quad$ Ibid para 56.

55 Ibid paras 23-24.

56 Ibid para 59. 'Organization-based volunteers' are defined to mean workers who perform any unpaid non-compulsory activities to produce goods or provide services for others through or for any type of organization or community group, but do not include unpaid trainees or 'workers performing unpaid compulsory activities': ibid para 71.

57 Ibid para 70.

58 On the general way the 2013 resolution classified forms of work, see Stewart and others (n 31) 18-19.

59 Resolution Concerning Statistics of Work, Employment and Labour Underutilization (Resolution I, 19th International Conference of Labour Statisticians in Geneva, 2-11 October 2013) para 33. 
'Unpaid' for this purpose means 'the absence of remuneration in cash or in kind, for work done or hours worked', although limited forms of support may be provided ${ }^{60}$ Specifically included are persons in unpaid traineeships, apprenticeships, internships or skills training or retraining schemes, when engaged in the production process of the relevant economic unit. ${ }^{61}$ However, the 2013 resolution excludes anyone undertaking a period of probation, general on-the-job learning, those in volunteer work and those learning while engaged in own-use production. ${ }^{62}$ The resolution also indicates that the acquisition of workplace experience or skills 'may occur through traditional formal or informal arrangements, whether or not a specific qualification or certification is issued' ${ }^{63}$

As both the 2013 and 2018 resolutions implicitly acknowledge, work and learning are not mutually incompatible, an issue discussed further by Rosemary Owens in Chapter 11 of this volume. However, in using the fact of payment (whether in cash or in kind) to differentiate 'learning' from 'work' and learning at work, the resolutions are of no assistance in identifying the problem of sham arrangements, or in answering the normative question of whether or not this learning at work should be paid.

\subsection{POLICY ISSUES}

There is a great deal of supportive literature about internships, especially from an educational perspective. A 2015 review of 57 studies on the impact of internships completed by university students concluded that they offer a 'win-win situation' for students, employers and higher education institutions, in enhancing employment opportunities, improving skills and competencies, and creating a better understanding of career paths. ${ }^{64}$ Interns themselves also tend to be satisfied with their experiences, as both the European and Australian surveys mentioned previously attest. In both cases a majority of respondents

60 Ibid para 33(c), which suggests that 'transfers of education stipends or grants' may be disregarded as not constituting remuneration, as well as 'occasional in cash or in kind support (eg a meal, drinks)'. It is not entirely clear whether something called a stipend, but doing more than reimbursing a very limited range of expenses, would be treated as remuneration for this purpose.

${ }^{61}$ Ibid para 34.

62 Ibid para 35. Once again, the definition of 'volunteer work' excludes 'unpaid work required as part of education or training programmes (i.e. unpaid trainees)': ibid para 38. However, nothing is specifically said to help distinguish volunteering from training.

${ }_{63}$ Ibid para 33(e).

${ }^{64}$ Gisela Sanahuja Vélez and Gabriela Ribes Giner, 'Effects of Business Internships on Students, Employers, and Higher Education Institutions: A Systematic Review' (2015) 52 J Employ Couns 121. 
who had undertaken a traineeship or work experience felt that it had improved or would improve their job prospects, even though only around a quarter found employment at the conclusion of their most recent experience. ${ }^{65}$

There is also a substantial body of research that identifies potential problems with internships - especially (although not exclusively) those in the open market. The concerns can be grouped into four main categories.

First, some internships may not deliver on the promise of useful training and skill development. The European Commission has estimated that at least 30 per cent of traineeships are deficient in either learning content or working conditions. ${ }^{66}$

Secondly, internships may not provide a bridge from education to paid work. There is a strongly entrenched perception that work experience enhances employability, on the basis that it 'improves skills, knowledge and experience, assists an individual to match their human capital profile to labour-market demands and enhances their long-term marketability'. ${ }^{67}$ Experiments have also shown that having internship experience improves a job applicant's chances of getting an interview. ${ }^{68}$ Yet, '[e]conometric analysis of the outcomes of unpaid work experience and the extent to which participation facilitates subsequent paid employment is scarce'. ${ }^{69}$ What evidence there is suggests that paid internships are associated with better labour-market outcomes than are unpaid internships, and that there may be advantages to undertaking more formally structured programmes..$^{70} \mathrm{~A}$ study in the UK has also suggested that graduates undertaking open-market internships earn less 3.5 years after graduation than those going straight into paid work or further study. ${ }^{71}$

65 TNS Political \& Social (n 44); Oliver and others (n 46).

66 European Commission, 'Executive Summary to the Impact Assessment Accompanying the Document "Proposal for a Council Recommendation on a Quality Framework for Traineeships"' (2013) European Commission Staff Working Document 496.

67 Grant-Smith and McDonald (n 29) 566.

68 Stijn Baert, Brecht Neyt, Thomas Siedler, Ilse Tobback and Dieter Verhaest, 'Student Internships and Employment Opportunities after Graduation: A Field Experiment' (2018) Discussion Paper No 12183, IZA Institute of Labor Economics.

69 Grant-Smith and McDonald (n 29) 566.

70 Niall O'Higgins and Luis Pinedo Caro, Chapter 3 in this volume; Wil Hunt and Peter Scott, 'Paid and Unpaid Graduate Internships: Prevalence, Quality and Motivations at Six Months after Graduation' (2020) 45 Stud Higher Educ 484.

71 Angus Holford, 'Access to and Returns from Unpaid Graduate Internships' (2017) IZA Institute of Labor Economics Discussion Paper No 10845. Compare the more positive wage outcomes from educational internships identified by Nils Saniter and Thomas Siedler, 'Door Opener or Waste of Time? The Effects of Student Internships on Labor Market Outcomes' (2014) IZA Institute of Labor Economics Discussion Paper No 8141. See also the studies noted by Sienkiewicz (n 6) 8. 
Thirdly, the practice of expecting or requiring unpaid or low-paid internships may impede social mobility. The cost of undertaking these internships is likely to be harder to bear for those from less advantaged backgrounds, especially if it is necessary to travel to an expensive location to find them. For example, British graduates from a middle-class background are more likely to have taken an internship, compared with those from the working class, while the latter are more likely to have worked in a paid job to subsidize their work experience, as opposed to relying on savings or parental support. ${ }^{72}$ Similarly, in Australia the likelihood of undertaking unpaid work experience increases according to socio-economic status, while participation is higher for those living in capital cities, compared with smaller towns or rural areas. ${ }^{73}$

Fourthly, the use of unpaid or low-paid internships may displace paid employment and undermine labour standards. Interns run the risk of being treated as 'cheap dead-end labour, exerting downward pressure on the wages and opportunities of others who might otherwise be employed' ${ }^{74}$ The International Labour Conference has also specifically highlighted this problem, ${ }^{75}$ as noted in section 2.1 of this chapter. Its resolution on the youth employment crisis called on governments to regulate and monitor apprenticeships, internships and other work experience schemes, 'to ensure they allow for a real learning experience and not replace regular workers' ${ }^{76}$ The same point has been acknowledged by the ILO's Committee of Experts on the Application of Conventions and Recommendations, in commenting that 'problems have been raised in several countries relating to unpaid internship programmes and other similar arrangements, when they are used to evade the payment of applicable minimum wages and to curtail employment opportunities'. ${ }^{77}$ Even some government-backed ALMP schemes may be open to criticism on this basis. ${ }^{78}$

\footnotetext{
72 Cullinane and Montacute (n 45).

73 Oliver and others (n 46).

74 Guy Standing, The Precariat: The New Dangerous Class (Bloomsbury Academic 2011) 76 .

75 ILO, 'The Youth Employment Crisis' (n 7) para 24.

76 Ibid para 26(e).

77 Committee of Experts on the Application of Conventions and Recommendations, Minimum Wage Systems: General Survey of the Reports on the Minimum Wage Fixing Convention, 1970 (No 131), and the Minimum Wage Fixing Recommendation, 1970 (No 135) (Report III (Part 1B), International Labour Conference, 103rd Session, International Labour Office 2014) para 187.

78 Eurofound, 'Fraudulent Contracting of Work: Abusing Traineeship Status (Austria, Finland, Spain and UK)' (Eurofound, 27 July 2017), www.eurofound.europa .eu/publications/information-sheet/2017/fraudulent-contracting-of-work-abusing -traineeship-status-austria-finland-spain-and-uk, accessed 30 March 2021.
} 
The ILO has recently acknowledged these four policy concerns, ${ }^{79}$ as part of the background to a proposal for a possible new convention and/or recommendation on the subject of 'quality apprenticeships'. A questionnaire issued to ILO member states in late 2019 has sought feedback on whether any new instrument(s) should contain a section on traineeships (including internships). There are specific questions about the possibility of states requiring a written traineeship agreement, as well as ensuring 'adequate remuneration' for trainees, among other benefits and protections. ${ }^{80}$

With all that in mind, it is surely important to learn more about the nature, value and impact of internships, to find out how they are being regulated around the world - and to consider carefully what might be done to preserve their potential benefits, while safeguarding against their misuse.

79 ILO, A Framework (n 21) 68-9.

80 Ibid $97-8$. 